\title{
Observing Sociology of Education in Japan From an Anglophone Periphery
}

\section{Kaori Okano}

I am one of the Japanese diaspora who has enjoyed a long academic career overseas. This paper will introduce my research interests, comment on sociology of education research in Japan and explore the potential that the Japan Society of Educational Sociology presents in contributing to the global research community.

I have held an academic position at an Australian university since 1991, and am currently Professor of Asian Studies/Japanese. I grew up and attended government mainstream schools in Japan until the completion of an undergraduate degree; and left for Australia to study for a Masters degree, inspired by a one year undergraduate exchange experience at a New Zealand university. I then became a fulltime teacher at secondary schools (Years 7 to 12) in Australia and New Zealand, discharging a variety of duties such as teaching subjects (social studies and Japanese), sport supervision, boarding house roles, and curriculum development. When I returned to university to commence a $\mathrm{PhD}$, these three years of teaching had significantly changed my perception of Japanese schooling. The experience provided me with both an outsider's and a practitioner's perspective, in terms of theoretical interest (inequality and multiculturalism) and particular aspects of Japanese education (disadvantaged children) In more recent years, observing my two children growing up in Australia also gave me another perspective as a parent, in particular, a parent from an ethnic minority.

My research interest has centred on how schooling simultaneously reproduces and ameliorates social inequality (class, ethnicity, gender, regions), a theme that has run through various projects I have undertaken. Diversity and social inequali- 
ty has been the subject of a comprehensive book on Japanese schooling that I $\mathrm{co}^{-}$ authored with a Japan-based academic (Okano and Tsuchiya 1999). This book was translated into Malay, and several reprint versions were used at universities and teachers' colleges in Malaysia and Indonesia (Okano \& Tsuchiya, 2004). The book aimed to provide a sociological overview of Japanese schooling to uninitiated readers, covering topics that would interest students and scholars outside Japan.

My first book, deriving from my $\mathrm{PhD}$ research, was an ethnographic study of working class high schoolers' school to work transition --- how they decided on, and eventually reached, their post-school destinations in the workforce, what factors (family, individual and the school's institutional mechanisms) were affecting their actions in this process, and how students and teachers interpreted the process (Okano 1993, 1995a, 1995b, 1997, 2000). This project has developed into a longitudinal study of growing up, tracing 21 working class girls (out of the cohort of more than 100 in the original 1989-1990 study) every few years to this day (e.g., Okano 2009a; 2004a). These girls are now 45 year old women. While begun as a sole-researcher project, more recently it has expanded into a collaborative interdisciplinary project with five sociolinguists based in Melbourne and Osaka. The project, 'Thirty years of talk: Real-time panel study of Kobe women's interview discourse 1989-2019', is a sociolinguistic analysis of language changes and variations over the time, in addition to the original focus on the sociology of growing up. The project received an Australian Research Council Discovery grant for 2017-2019.

With a broad interest in diversity and social inequality, my research has examined minorities and multiculturalism (Okano 2004b, Tsuneyoshi, Okano \& Boocock, Eds., 2011; 2006a, 2013a, 2014a), race/ethnicity (Okano, 2014b), indigenous people (e.g., Okano 2013b), migrants (2017 in press), and language and citizenship (Okano 2012). I have also worked on culture of schooling (Okano 2009b; 2011) and neoliberal education reform (Okano 2009c), in a comparative perspective. One of my more recent interests has been a relatively unexamined area, the teaching and learning that occur outside formal schooling. Building on the two major works in this area (Rohlen \& LeTendre, Eds., 1996; Singleton, Ed., 1998), I edited a book on nonformal education and civil society which focused on nonformal educa- 
tion's interface with the mainstream schooling (Okano, Ed., 2016).

In my work as an editor (whether of a book or the special issue of journal) I have made an effort to introduce research by Japan-based scholars. I edited the Japanese civilisation section of the Handbook of Asian Education (Zhao et al., Eds., 2011), and books on language in education in Asia (Okano, Ed., 2006b), minority and multiculturalism (Tsuneyoshi, Okano \& Boocock, Eds., 2011), and nonformal education and civil society (Okano, Ed., 2016). Working with these and other Japan-based scholars has resulted in productive outcomes.

There is a body of excellent research in the sociology of education in Japan, as seen in the Society's journal and other sociology journals, but it seems that the field shares prevailing features with other social sciences. One is a relatively limited flow of research from Japan to the global research conversation - for example, we see trendy social theories in the West quickly become available in Japanese translation, which Japan-based scholars eagerly refer to in explaining local phenomena. The fact that academic translation into Japanese is considered academic output encourages translation activity (while in Anglophone academia translations are not ranked highly in terms of academic output). In comparison to social theories, relatively little attention seems to be paid by Japan-based scholars to English language empirical work on Japanese schools, including ethnographies (e.g., Sato, 2003; LeTendre, 2000; Cave, 2016; Bjork, 2016). Japan-based scholars do develop new tentative hypotheses, but they are often not communicated to the global scholarly community. The other feature is that overseas research refereed by Japan-based scholars often comes from the West. This is a dominant trend not only in Japan but also in the global academy whereby the point of comparison remains the West (Chen, 2010). There are studies that defy this trend (e.g., Park, 2014), by examining Japan alongside some Asian societies as a point of comparison. They are however exceptions.

These two features derive from Eurocentrism, the fact that the Anglo-West has historically exerted an unhealthy dominance in knowledge production. The position of English as the de facto lingua franca for global academic communication demands that research findings be made available in English. The AngloWest now constitutes the academic 'centre' where universalistic theories (which 
are deemed as being of a higher order of knowledge) are generated and legitimated, while the rest of the world remains the periphery that is expected to provide primary sources, or to apply these universalistic theories in socially and culturally particular contexts. Oguma (2018 in press) offers an additional explanation that the relative reluctance of Japan-based scholars to publish in English (in comparison to other non-Anglophone countries) is due to the 'self-sufficiency' of Japanese publishing, whereby Japan-based academics have relatively little incentive to publish in English. This entrenched attitude is currently challenged by institutional requirements designed to make Japanese universities more competitive globally (e.g., as defined by world university rankings) (e.g., Ishikawa, Ed., 2016). Sociology of education in Japan perhaps maintains a higher degree of autonomy or independence from the global (Anglophone) research, precisely because scholars have not needed to publish in English to the same extent as some Asian neighbours. And the autonomous nature of research has some merits

Japan's institutional push for 'internationalization' of scholarship and global competitiveness pressures Japan-based scholars to publish in English, but blindly 'internationalising' sociology of education may advance the Eurocentric trends mentioned above. As non-Western societies grew prosperous, sociology of education has spread in other parts of Asia and elsewhere, involving larger numbers of 'local' scholars. But as many of them received training in the Anglo-West, and later increasingly faced institutional pressures to conform to the globally established norms in order to survive in academia, we may face a dilemma. On the one hand, research in sociology of education involves a larger number of scholars more widely dispersed geographically than before, but this does not mean that scholarship has become less Eurocentric (Okano, 2018 in press). Research in sociology of education may have become more Eurocentric now than three decades ago.

Having discussed Eurocentrism in sociology of education, I see the great potential in Journal of Educational Sociology and the Japan Society of Educational Sociology. The Journal could play major roles in advancing the kind of research which has multiple points of comparison ---- e.g., Anglophone world, Japan and the rest of Asia. There are a large number of students from Asia completing 
postgraduate research training at Japanese universities on government scholarships, more than in many other non-Western countries; which can be capitalized on for such projects. There are Asia-based English language journals of education such as the Asia-Pacific Journal of Education (Singapore based), Asia-Pacific Education Review (Seoul based), and the Educational Research Journal (Hong Kong based). I think that the Society could consider publishing a Japan-based alternative in English, introducing research by Japan-based scholars and encouraging conversation with overseas-based scholars (not only those in Anglophone societies). Observing and writing on Japanese schooling from Australia, I remain optimistic about the future of sociology of education in Japan.

\section{References}

Bjork, C. (2016). High-stakes schooling: What we can learn from Japan's experiences with testing, accountability \& educational reform. Chicago: Chicago University Press.

Cave, P. (2016). Schooling selves: Autonomy, interdependence, and reform in Japanese junior high education. Chicago: Chicago University Press.

Chen, K.H. (2010). Asia as Method: Toward Deimperialization. Durham, NC: Duke University Press.

Ishikawa, M. (Ed.) (2016). Sekai daigaku rankingu to chi no joretsuka. Kyoto: Kyoto University Press.

LeTendre, G. (2000). Learning to be adolescent: growing up in US and Japanese middle schools. New Heaven: Yale University Press.

Oguma, E. (2018 in press). Studying Japan as 'the Other': A Short History of Japanese Studies and Its Future. In K. Okano \& Y. Sugimoto (Eds.), Rethinking Japanese Studies: Eurocentrism and the Asia-Pcific Region. London \& New York: Routledge.

Okano, K. (1993). School to work transition in Japan: An ethnographic study. Clevedon, Avon: Multilingual Matters.

Okano, K. (1995a). Habitus and intraclass differentiation: nonuniversity-bound students in Japan. International Journal of Qualitative Studies in Education, 8 ( 4 ), 357-369. 
Observing Sociology of Education in Japan From an Anglophone Periphery

Okano, K. (1995b). Rational decision making and school-based job referrals for high school students in Japan. Sociology of Education, 68 ( 1), 31-47.

Okano, K. (1997). Third-generation Koreans' entry into the workforce in Japan. Anthropology and Education Quarterly, 28 ( 4 ), 524-549.

Okano, K. (2000). Social justice and job distribution in Japan: class, minority and gender. International Review of Education, 46 ( 6 ), 545-565.

Okano, K. (2004a). Japanese working class girls in their first employment: Transition to adulthood. Journal of Education and Work, 17 ( 4 ), 421-439.

Okano, K. (2004b). Minority's changing relationship with schools. International Review of Education, 49 ( 6 ), 1 -22.

Okano, K. (2006a). The global-local interface in multicultural education policies in Japan. Comparative Education, 42 ( 2), 473-491.

Okano, K. (Ed.) (2006b). Languages and schools in Asia: Globalization and local forces. Special issue of Langauge and Education, 20 ( 4).

Okano, K. (2009a). Young women in Japan: Transitions to adulthood. London: Routledge.

Okano, K. (2009b). School culture. In Y. Sugimoto (Ed.), The Cambridge companion to modern japanese culture (pp. 92-112). Cambridge: Cambridge University Press.

Okano, K. (2009c). Education reforms in Japan: Neo-liberal, neo-conservative, and "progressive education" directions. In D. Hill (Ed.), The rich world and the impoverishment of education (pp. 238-258). New York: Routledge.

Okano, K. H. (2011). Adaptive learning at the global periphery: Cultural overview of education in Japanese civilization. In Y. Zhao, J. Lei, G. Li, M. F. He, K. Okano, N. Megahed, D. Gamage, \& H. Ramanathan (Eds.), Handbook of Asian education: A cultural perspective (pp. 183-198). New York: Routledge.

Okano, K. (2012). Language and citizenship in education: Migrant languages in government schools. In N. Gottlieb (Ed.), Language and citizenship in Japan (pp. 58-78). London: Routledge.

Okano, K. (2013a). Ethnic Schools and Multiculturalism in Japan. In G. DeCoker \& C. Bjork (Eds.), Japanese Education in the Era of Globalization (pp. 85-100). New York: Teachers College Press. 
Okano, K. (2013b). Indigenous Ainu and Education in Japan: Social Justice and Culturally Responsive Schooling. In R. G. Cravan, G. Bodkin-Andrews, \& J. Mooney (Eds.), Indigenous Peoples (pp. 3-25). Charlotte, North Carolina: Information Age Publishing.

Okano, K. (2014a). From 'internationalization' to 'multicultural co-living' in Japanese schools. In C. Stevens, S. Steele, \& J. Breaden (Eds.), Internationalizing Japan (pp. 53-67). London: routledge.

Okano, K. (2014b). Japan. In P. Stevens \& G. Dworkin (Eds.), The Palgrave handbook of race and ethnic inequalities in education (pp. 422-449). New York: Palgrave.

Okano, K. (Ed.) (2016). Nonformal education and civil society in Japan. London \& New York: Routledge.

Okano, K. (2017). Education of new migrants and the civil society in Japan: Nongovernmental organisations and ethnic schools. In K. E. Kuah \& J. E. T. Tan (Eds.), Educating marginilized communities in East Asia. London \& New York: Routledge.

Okano, K. (2017 in press). Transnational migration and urban education in Japan. In W. T. Pink \& G. W. Noblit (Eds.), International handbook of Urban Education: Springer.

Okano, K. (2018 in press). Rethinking 'Eurocentrism' and area studies: Japanese Studies in the Asia-Pacific. In K. Okano \& Y. Sugimoto (Eds.), Rethinking Japanese Studies. London \& New York: Routledge.

Okano, K., \& Sugimoto, Y. (Eds.). (2018 in press). Rethinking Japanese Studies: Eurocentrism and the Asia-Pacific Region. London \& New York: Routledge.

Okano, K., \& Tsuchiya, M. (1999). Education in contemporary Japan: Inequality and diversity. Cambridge: Cambridge University Press.

Okano, K., \& Tsuchiya, M. (2004). Pendidikan moden Jepun: Ketaksamaan dan kepelbagaian. Kuala Lumpur, Institut Tergemeha Nagara Malaysia Berhad, Reprint 2006, 2007, 2008, 2009.

Park, H., \& Chang, P. (2014). Re-evaluating education in Japan and Korea: Demystifying stereotypes. Journal of Asian Studies, 73( 4 ), 1142-1143.

Rohlen, T., \& LeTendre, G. (Eds.). (1996). Teaching and Learning in Japan. New 
Observing Sociology of Education in Japan From an Anglophone Periphery York: Cambridge University Press.

Sato, N. (2003). Inside Japanese classrooms: the heart of education. New York: RoutledgeFarmer.

Singleton, J. (Ed.) (1998). Learning in likely places: Varieties of apprenticeship in Japan. Cambridge: Cambridge University Press.

Tsuneyoshi, R., Okano, K., \& Boocock, S. (Eds.). (2011). Minorities and education in multicultural Japan: a interactive perspective. London: Routledge.

Zhao, Y., Lei, J., He, M. F., Okano, K., Gamage, D., Hema, R., \& Nagwa, M. (Eds.). (2011). Handbook of Asian Education: A cultural perspective. New York: Routledge. 